\section{The Impact of a Pedagogy Course on the Teaching Beliefs of Inexperienced Graduate Teaching Assistants}

\section{Star W. Lee*}

Department of Evolution, Ecology, \& Organismal Biology, University of California, Riverside, Riverside, CA 92521

\begin{abstract}
There has been little attention given to teaching beliefs of graduate teaching assistants (GTAs), even though they represent the primary teaching workforce for undergraduate students in discussion and laboratory sections at many research universities. Secondary school education studies have shown that teaching beliefs are malleable and can be shaped by professional development, particularly for inexperienced teachers. This study characterized inexperienced GTAs' teaching beliefs about student learning and how they change with a science-specific pedagogy course that emphasized student learning. GTA teaching beliefs were characterized as traditional (providing information to students), instructive (providing activities for students), and transitional (focusing on student-teacher relationships). At the start of the course, traditional, instructive, and transitional beliefs were emphasized comparably in the concept maps and presentations of inexperienced GTAs. At the end of the course, although GTAs' beliefs remained mostly teacher focused, they were more instructive than traditional or transitional. GTAs included teaching strategies and jargon from the course in their concept maps but provided minimal explanations about how opportunities for active student engagement would impact student learning. These results suggest there is a need to provide ongoing discipline-specific professional development to inexperienced GTAs as they develop and strengthen their teaching beliefs about student learning.
\end{abstract}

\section{INTRODUCTION}

Graduate school is designed to mold the professional identity of science, technology, engineering, and mathematics (STEM) graduate students as scientists with the intention of pursuing a career in research, with less emphasis on supporting the development of future instructors (Brownell and Tanner, 2012). This is particularly problematic for graduate students who end up in academic jobs with primarily teaching responsibilities (Golde and Dore, 2001; Gardner and Jones, 2011; Brownell and Tanner, 2012). Most STEM graduate students teach undergraduate students in some capacity, including being a teaching assistant, research mentor, and/or guest lecturer (Connolly et al., 2016). At many research universities, graduate teaching assistants (GTAs) teach a majority of undergraduate discussion and lab sections for biology courses (Rushin et al., 1997; Sundberg et al., 2005). Teaching experience provides GTAs with opportunities to not only build skills in the classroom (Connolly et al., 2016), but also strengthen their research preparation and skills (Feldon et al., 2011; Shortlidge and Eddy, 2018). The teaching experience of GTAs may be supported by teaching professional development (PD), which may lead to increased teaching self-efficacy, knowledge, and skills (DeChenne et al., 2012; Marbach-Ad et al., 2012; Wyse et al., 2014; Connolly et al., 2018; Reeves et al., 2018). Exposing GTAs to discipline-based education research has the potential to change teaching practices of future faculty (Dancy et al., 2016) and improve undergraduate student learning in STEM courses.
Cynthia Brame, Monitoring Editor Submitted Jul 26, 2018; Revised Nov 21, 2018: Accepted Nov 28, 2018

CBE Life Sci Educ March 1, 2019 18:ar5 DOI:10.1187/cbe.18-07-0137

*Address correspondence to: Star W. Lee (star.lee@ucr.edu).

(c) 2019 S. W. Lee. CBE-Life Sciences Education () 2019 The American Society for Cell Biology. This article is distributed by The American Society for Cell Biology under license from the author(s). It is available to the public under an Attribution-Noncommercial-Share Alike 3.0 Unported Creative Commons License (http://creativecommons.org/ licenses/by-nc-sa/3.0).

"ASCB®" and "The American Society for Cell Biology ${ }^{\circledR}$ " are registered trademarks of The American Society for Cell Biology. 
Teaching PD for STEM GTAs is highly variable among institutions, with differences in organizational structure and format, target audience, duration, level of engagement, and content focus, among other features (Rushin et al., 1997; Schussler et al., 2015; Connolly et al., 2016). Most GTAs participate in a single-day training workshop focused on broader campus issues with minimal attention to general or discipline-specific pedagogy training (Rushin et al., 1997; Park, 2004; Schussler et al., 2015; Connolly et al., 2016). Evaluations of these experiences suggest that these types of institution-wide orientations for GTAs may be too general and may not be applicable to science GTAs (Luft et al., 2004). Most institutions do not offer a departmental pedagogy seminar for GTAs, and fewer than half of graduate students enroll in a formal PD course on teaching (Schussler et al., 2015; Connolly et al., 2016). Teachers need to be knowledgeable about not only general pedagogy, but also the intricacies of teaching specific subject matter, which is termed "pedagogical content knowledge" (PCK; Shulman, 1986). PCK consists of the teachers' knowledge and beliefs about the purposes of science teaching, goals and objectives for students, students' preconceptions about and challenges in learning science, assessment of science learning, and content-specific instructional strategies (Magnusson et al., 1999).

Beginning teachers face a number of challenges, including mastering content knowledge, understanding learners and instruction, and learning environments (Davis et al., 2006). Beginning teachers exhibit limited PCK and develop PCK with classroom experience (Lee et al., 2007). In the absence of PD and support at the start of their careers, beginning teachers struggle on their own with a variety of issues, including lesson planning, administrative problems, and classroom management (Luft et al., 2003). Typically, GTAs are the sole instructors in their classrooms (Sundberg et al., 2005), and they receive little to no guidance or feedback regarding teaching (Jones, 1993; Austin, 2002; Park and Ramos, 2002; Luft et al., 2004). GTAs often struggle with facilitating discussions and motivating student participation (Gormally et al., 2016). Without input from teaching mentors, graduate students revert to strategies they encountered as undergraduates, using primarily teacher-centered strategies (Gormally et al., 2016). This is particularly true for inexperienced GTAs, who have limited knowledge of pedagogy and classroom experience. It is critical to support new teachers, particularly during the first year of teaching when the development and strengthening of teachers' beliefs, PCK, and practices occurs (Feiman-Nemser, 2001; Davis et al., 2006; Lee et al., 2007; Luft, 2009).

Teaching practices are influenced by a number of factors, including teachers' beliefs and views on teaching and context (Keys and Bryan, 2001; Norton et al., 2005). Although related, teachers' beliefs are thought to be distinct from knowledge and practice (Nespor, 1987; Pajares, 1992). Teachers' beliefs help to define teaching and the goals of teaching, and beliefs play a significant role in teaching behavior (Nespor, 1987; Pajares, 1992). Beliefs are drawn from personal experiences, are influenced by affective states, may include contradictions, and are more resistant to change than knowledge systems (Nespor, 1987). Teaching beliefs and practices can range from teacher focused and traditional to student focused and reform based (Trigwell et al., 1994; Luft and Roehrig, 2007). Teacher-focused beliefs and practices highlight the role of the teacher in trans- mitting information to students; student-focused beliefs and practices emphasize the role of the students in developing their own ideas and conceptions (Trigwell et al., 1994; Luft and Roehrig, 2007). Shifting teaching beliefs to be more student focused increases the likelihood of teachers implementing student-focused teaching practices (Henderson et al., 2011).

With the Teacher Beliefs Interview (TBI), teacher beliefs can be further classified into one of five categories: traditional or instructive (teacher focused), transitional, or responsive or reform based (student focused; Luft and Roehrig, 2007). Traditional beliefs emphasize transferring information from the teacher to students, which is exemplified by lecturing. Instructive beliefs focus on providing students with experiences and opportunities to learn, and the student learning is directed by the teacher. Transitional beliefs stress developing the teacherstudent relationship and providing a supportive learning environment for the student. Responsive beliefs emphasize collaborative learning among the students. Reform-based beliefs focus on students driving their learning based on their prior knowledge and individual needs. The TBI categories allow for further differentiation of beliefs with the progression of categories from teacher-focused to student-focused beliefs.

Teaching beliefs of GTAs range from teacher focused to transitional, which may be influenced by their teaching experience and PD programs (Roehrig et al., 2003; Luft et al., 2004; Addy and Blanchard, 2010; Douglas et al., 2016). Inexperienced GTAs believe that their role is to provide information to the students in a clear and organized manner and that student learning depends on students' efforts and ability to follow instructions (Roehrig et al., 2003). Experienced GTAs also exhibit teacher-focused beliefs and practices (Addy and Blanchard, 2010; Luft et al., 2004; Douglas et al., 2016). Teaching experience alone does not translate into adopting more student-focused approaches to teaching (Norton et al., 2005; Postareff et al., 2008). Changing teaching beliefs may depend on the type of PD. With general PD, biology, chemistry, and physics GTAs are teacher focused and instructive in their approach to teaching; GTAs express the need for students to be given explicit instructions and content, which may stem from GTAs' own experiences as students (Luft et al., 2004). GTAs who receive a form of departmental training hold beliefs on student learning that range between teacher focused to transitional (Douglas et al., 2016). At the completion of a year-long reform-based teaching certificate, biology GTAs with 1-5 years of teaching experience exhibit beliefs about student learning that are transitional, that is, the emphasis is on the teacher-student interactions (Addy and Blanchard, 2010). However, without knowledge of the GTAs' beliefs before the program, it is difficult to evaluate the impact of PD on experienced GTAs' beliefs. The length of the PD represents another critical variable in changing teaching beliefs and practices. At least one semester of PD is recommended to impact teaching beliefs and practices of instructors (Henderson et al., 2011).

GTAs' teaching beliefs and how they change with PD are not well studied. Providing discipline-specific PD increases the likelihood of shifting secondary science teachers' beliefs from being teacher-centered to more student-centered (Luft, 2009). Without PD, biology GTAs exhibit teacher-focused beliefs and strategies wherein content knowledge is paramount, with minimal regard to the role of the students in the learning process 
(Hammrich, 2001). After completing a science-specific pedagogy seminar, biology GTAs emphasized the importance of using pedagogical strategies to help their students (Hammrich, 2001). Without discussion of how GTAs would implement the strategies, it is unclear whether biology GTAs' beliefs changed from teacher focused to student focused. Another factor in changing teachers' beliefs is the stage of the teaching career in which the PD is provided; inexperienced secondary science teachers are more likely to change their beliefs compared with experienced teachers (Luft, 2001). Inexperienced GTAs' beliefs are potentially more malleable than those of experienced GTAs. However, the impact of a discipline-specific PD program on inexperienced GTAs' teaching beliefs is unknown.

In addition to interviews and surveys, concept maps represent another approach to gather qualitative data to evaluate teachers' cognition. Concept maps are a useful tool in organizing and illustrating knowledge (Novak and Gowin, 1984; Novak and Canas, 2008), and they are used in education as both a learning tool for students and a research and evaluation tool for instructors (Markham and Mintzes, 1994; Nesbit and Adesope, 2006). In teacher education studies, concept maps have been used to assess teachers' knowledge, beliefs, and attitudes regarding STEM concepts, the nature of science, research, and pedagogy (Kagan, 1990; Zanting et al., 2003; Borda et al., 2009; Chichekian and Shore, 2013; van der Linden et al., 2015). Concept maps and surveys were used to monitor how preservice teachers' views on science changed after instruction on the nature of science (Borda et al., 2009). While the type of information provided was different, common themes emerged in both the concept maps and surveys (Borda et al., 2009). Comparing concept maps and interviews provided different perspectives in the evaluation of teachers' practical knowledge, which consists of knowledge, beliefs, and values that impact their teaching (Zanting et al., 2003). Both concept maps and interviews were valid tools in assessing teachers' practical knowledge, with concept maps being effective in prompting teachers to share teaching beliefs (Zanting et al., 2003).

Comparing successive concept maps from students can illustrate changes in their knowledge structures (Carey, 1986; van der Linden et al., 2015). Preservice teachers' views on research were evaluated before and after an introductory course on research, using pre- and postcourse concept maps (van der Linden et al., 2015). The postcourse concept maps were more focused and included more relevant topics compared with the precourse maps, demonstrating comparison of concept maps can be used to track changes in beliefs (van der Linden et al., 2015). After completing teacher education programs, preservice teachers drew more detailed maps of effective teaching (Beyerbach and Smith, 1990) and more connections between concepts (Lederman et al., 1994; Jones and Vesilind, 1996). Evaluation of concept maps highlighted differences in how teachers emphasized various aspects of teaching (Morine-Dershimer et al., 1992). Though concept maps are sensitive to detecting how teachers view and integrate concepts of effective teaching (Beyerbach and Smith, 1990; Morine-Dershimer et al., 1992; Lederman et al., 1994; Jones and Vesilind, 1996), they have yet to be used to capture GTAs' beliefs surrounding teaching. This study investigates biology GTAs' beliefs about student learning using concept maps.
This study addressed the following research questions:

1. What are inexperienced biology GTAs' beliefs about student learning?

2. Does participation in a quarter-long science pedagogy course change inexperienced GTAs' beliefs about student learning?

\section{METHODS}

\section{Study Participants}

This study was conducted in the Winter and Spring quarters of 2018 at a large undergraduate university with a Carnegie basic classification of doctoral university: highest research activity. It is a Hispanic-serving institution with $38 \%$ of the undergraduate student population identifying as Hispanic or Latinx, with a similar proportion being STEM majors. The study was approved by the institutional review board (protocol number HS-17-212) before all data collection.

All GTAs are required to attend a one-day, campus-wide teaching assistant orientation. Topics for the campus-wide orientation include undergraduate resources; responsibilities, resources, and rights of GTAs; rapport and diversity; and organization, knowledge, and instruction. Graduate students in the life sciences teach an average of six quarters, ranging from three to nine quarters; these courses may be in multiple departments. GTAs teaching a course in the biology department for the first time are required to enroll in a graduate-level course called "Biology 301: Teaching of Biology at the College Level." This is the only required course at the university designed to support GTAs during their teaching experiences by providing content-specific pedagogical training.

GTAs were recruited for this study during the first day of class in the Winter (24 students enrolled) and Spring (10 students enrolled) quarters of 2018. Multiple sections were offered to limit the enrollment to a maximum of 10 students. Of the 34 students enrolled in Biology 301, 91\% of the students $(n=31)$ agreed to participate in the study. All 31 GTAs, 16 females and 15 males, were full-time graduate students pursuing doctoral degrees in the life sciences. During the course of the study, they were enrolled in Biology 301 and concurrently teaching one of the following: introductory biology lab courses for majors $(n=$ 20 ), nonmajors biology lab courses $(n=7)$, or upper-division biology courses $(n=4)$. Most of the GTAs were first-time GTAs $(n=23)$, having no experience teaching in any department. Eight GTAs had previous teaching experience for one quarter $(n=5)$, two quarters $(n=2)$, or four quarters $(n=1)$ in another department.

\section{GTA Teaching Responsibilities}

In the introductory biology courses for majors and nonmajors, undergraduate students were enrolled concurrently in the lecture and laboratory sections. Faculty taught the lecture sections; GTAs taught the laboratory sections. GTAs taught two laboratory sections, each with 24 students. Each laboratory section met once a week for 3 hours for eight or nine times during the quarter. In addition to teaching, GTAs were responsible for maintaining a course management website, grading weekly assignments, writing quizzes, proctoring exams, and holding weekly office hours. GTAs were supported by an academic coordinator who provided laboratory course materials and weekly teaching preparatory meetings. During the weekly teaching 
preparatory meetings, the academic coordinator reviewed the lab procedures, equipment and materials to be used, and potential challenges for students. The curricula of the biology labs ranged from cookbook to guided-inquiry labs.

For upper-division courses, there were no laboratory sections. Faculty taught the lecture section; GTAs taught the discussion sections. GTAs taught four discussion sections, each with 25 students. Depending on the course, GTAs were responsible for maintaining a course management website, grading weekly assignments, writing quizzes, proctoring exams, and/or holding weekly office hours. GTAs were supported by the faculty teaching the lecture section; the level of support and interactions between GTAs and faculty varied depending on the faculty member. For example, faculty may provide a detailed lesson plan or simply ask GTAs to review and answer questions about the lecture material. Each discussion section met once a week for 50 minutes for nine or 10 times during the quarter.

\section{Biology 301: Teaching of Biology at the College Level}

Biology 301 was designed to teach graduate students the fundamental concepts of science teaching pedagogy and how to engage students in the classroom. Recommendations for teaching PD include being discipline specific, emphasizing student learning, practicing pedagogical skills, incorporating active learning, encouraging collective participation and constructive interactions among peers, and providing opportunities to self-reflect on teaching and long-term support (Luo et al., 2000; Garet et al., 2001; Park, 2004; Gardner and Jones, 2011). The design of the course was based on the recommendations to increase the likelihood of GTAs implementing best practices, rooted in discipline-based education research. The features of GTA training can directly impact GTA cognition, such as knowledge, attitudes, and beliefs about teaching (Reeves et al., 2016).

The course was taught by the author and two other academic coordinators who are knowledgeable and implement best practices from science education research. The course syllabus is included in the Supplemental Material. The class met weekly for 50 minutes across the quarter (10 weeks). Each week, GTAs shared their classroom experiences, which was essential, as they realized others had similar struggles in the classroom, and this provided an opportunity for GTAs to receive and provide peer feedback. To support the development of PCK, GTAs were assigned to read a pedagogy paper weekly; topics included: classroom discourse, active learning, metacognition, inclusivity, formative assessment, and cooperative learning. To demonstrate how to engage students, weekly discussions of the course topics involved active-learning techniques. The active-learning activity served as a starting point for the discussion around the primary literature article. Discussions revolved around how the teaching strategy may be implemented in the classroom to improve student learning. GTAs were also required to find or develop and present their own active-learning activities to teach concepts applicable to their teaching assignments. GTAs answered questions regarding the rationale for their active-learning activities (Supplemental Material). Opportunities for self-reflection were embedded within classroom discussions and biweekly reflections on their teaching and implementation of new strategies.

\section{Data Collection and Analysis}

Generation of Concept Maps. On the first day of class (week 1 , precourse maps) and last day of class (week 10, postcourse maps) in the Winter and Spring quarters 2018 for Biology 301, GTAs were provided with a focus question and the following instructions (adapted from Allen and Tanner, 2003) to generate a concept map:

Question: How do you get students to learn?

1. Brainstorming stage: As a group, generate a list of terms that come to mind.

2. Organizing stage: Establish a hierarchical ordering of words from most to least general/important.

3. Layout stage: Begin to sketch out the map. The concepts can be written within boxes/circles. Arrange with the hierarchy in mind (more general at the top; less general at the bottom).

4. Linking stage: Establish lines and words to link the concepts together. Write the word/phrase that describes the connection between the concepts.

On the first day of class, students were asked to get into groups of three to four students. They were provided with a large piece of paper (21 by 33 inches), Post-it notes, and markers to make the concept maps. Students were not provided with a list of concepts, linking words, or the skeleton or structure of a map. Engaging in concept maps in groups may be more effective for student learning and encourage student discourse than producing individual concept maps (Okebukola and Jegede, 1988; van Boxtel et al., 2002). Additionally, concept maps generated by groups allow for sampling a population of GTAs more efficiently than traditional interviews, which may be more time-consuming. In the self-assigned groups, GTAs were given 20 minutes to generate their concept maps. Each group $(n=8)$ presented a map to the class, and these presentations were audio-recorded by S.W.L. On the last day of class, students were given the exact same concept map prompt and asked to get into groups of three to four students. The composition of the groups may have been slightly different between the pre- and postcourse groups, depending on students' preferences. Students were asked to present their concept maps, and students self-selected their presenters. Depending on the group, one or all members of the group spoke during the presentation. Students were given as much time as they needed to present the map. Presentations of the maps averaged 4 minutes in length, ranging from 2 to $8 \mathrm{~min}$ utes. A total of 16 concept maps and presentations (eight precourse maps, eight postcourse maps) were collected and audiorecorded. Time permitting, clarifying questions were asked during the presentations. For students who did not give consent, their portions of the concept map presentations were excluded and removed before data analysis.

Concept Map Coding and Analysis. Concept map presentations were transcribed verbatim for qualitative analysis. GTAs wrote down a single term/idea on individual Post-it notes and drew lines linking the terms. The terms written on the Post-it notes were compiled for each concept map. For example, in the precourse map for group 6 (Figure 1), the list of terms included active participation, hands-on activities, drawing support, humor, examples and analogies, repetition, keeping a pace, get 


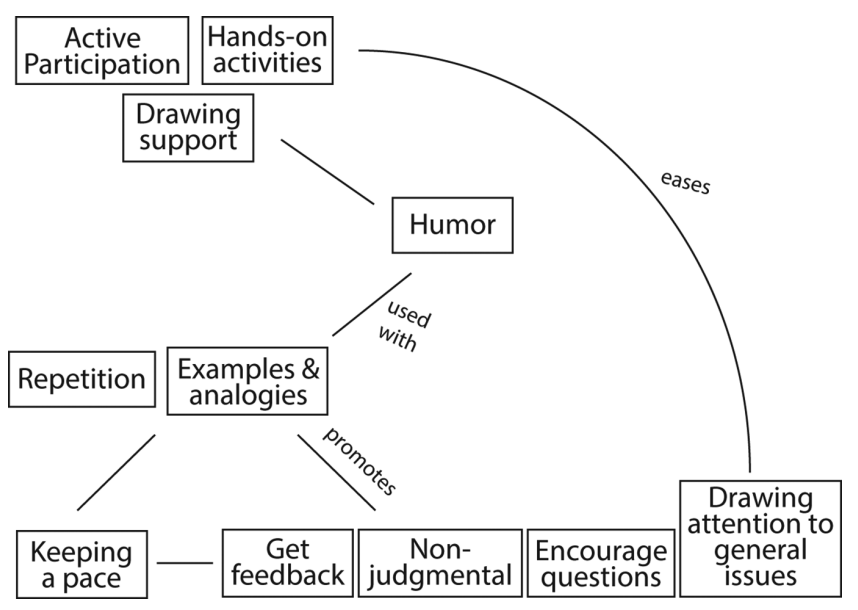

FIGURE 1. Representative precourse map of inexperienced GTAs' teachers' beliefs concerning student learning.

feedback, nonjudgmental, encourage questions, and drawing attention to general issues. Subsequently, each term was coded according to the TBI, which classifies secondary science teachers into one of five categories: traditional (teacher focused), instructive (teacher focused), transitional, responsive (student focused), or reform based (student focused; Table 1; Luft and Roehrig, 2007). The TBI consists of a set of seven questions to provide insight into how the teachers view student learning and the role of the teacher. The first question of the TBI, "How do you maximize student learning in the classroom?," is similar to the concept map focus question "How do you get students to learn?"

Luft and Roehrig (2007) provided example statements of how teachers responded to their questions in the TBI, and the descriptions and example statements provided in their tables and figures served as the foundation for the coding rubric. Coding focused on what the students were doing and how GTAs supported their learning. Students were described to be passive in only the traditional beliefs; students were active in some manner in the other TBI categories. From instructive to reform-based beliefs, the actions of the teacher varied in how GTAs interacted with students. In instructive, the teacher appears to be less involved while students complete the activity. In transitional, the teacher fosters the student relationship and creates a supportive learning environment. In responsive, the teacher designs activities for and supports peer learning. In reform-based, the teacher facilitates student learning based on individual needs.

After compiling a list of terms from each map, the concept map presentation was used to categorize each term. Each term was coded based on the explanation provided by GTAs during the concept map presentation and assigned based on the alignment with the goal of the given category (Table 1). The term was coded as traditional if GTAs used the term in the context of delivering information to students. The term was coded as instructive if GTAs used the term in the context of providing students with an experience or opportunity to help them learn without details of the GTAs' role in facilitating the learning process. The term was coded as transitional if GTAs used the term in the context of the relationship between the GTA and students. The term was coded as responsive if GTAs used the term in the context of providing students with an experience or opportunity to help students learn and provided details of how peer learning would occur in the process. The term was coded as reform based if GTAs used the term in the context of providing students with an experience or opportunity to help student learn and provided details of the GTAs' role in facilitating the learning process.

Table 1 provides examples of how terms were coded and the statements from the concept map presentations. "Describe concepts" was coded as traditional, because GTAs discussed giving anecdotes from science to students. There is no mention of the students, and one may assume the students are listening as the GTAs explain concepts. "Univocal" was coded as traditional, because GTAs discussed lecturing as an example of univocal discourse. "Hand-on activity" and "drawing to learn" were both coded as instructive, because GTAs mentioned them as activities to give students to do. The explanation did not go beyond providing students with the experiences. "Relatable" and "care for diversity" were coded as transitional, as these are aspects of teaching that impact the student-teacher relationship and classroom environment. Additional example terms and statements are provided in Table 2 .

For each map, the number of terms for each TBI category was totaled and used to determine what percentage of an individual map included traditional, instructive, transitional, responsive, and reform-based terms. For example, if the map had 10 terms, of which three were traditional, four instructive, and three transitional, then the map would be $30 \%$ traditional, $40 \%$ instructive, and 30\% transitional. Using the percentage of traditional, instructive, and transitional beliefs ensured that calculations of the mean and SEM were less dependent on the total number of terms. Each map was equally weighted in the calculation of the mean and SEM. The mean and SEM were calculated for the eight precourse maps or eight postcourse maps. During the analysis, the researcher was blind to the conditions of the concept maps and presentations. To ensure interrater reliability, a second individual coded a quarter of the concept maps and presentations. Both individuals coded the data separately. There was agreement $93 \%$ of the time, and discussions occurred until 100\% agreement was met. Owing to strong agreement, the author coded the remaining maps alone. A researcher coded each map twice to ensure intrarater reliability with $96 \%$ agreement.

Statistical Tests. A two-way analysis of variance (ANOVA) with repeated measures and Tukey's post hoc tests were used to determine significant differences among TBI categories in the pre- and postcourse maps.

\section{RESULTS}

\section{Precourse Concept Maps Dominated by Teacher-Focused Ideas on Learning}

The concept maps generated at the beginning of the pedagogy course (precourse maps) consisted of mainly teacher-focused approaches to student learning. The terms on the precourse maps were categorized as follows: $32.63 \%$ traditional, $45.44 \%$ instructive, and $21.93 \%$ transitional (Figure 2). There were no terms that were categorized as responsive or reform based. There were no significant differences between the TBI categories in the precourse maps. An example precourse map from group 1 is shown in Figure 1. The frequency of common themes in the precourse maps is quantified in Table 2. Common themes 
TABLE 1. Categories and descriptions adapted from the TBI (Luft and Roehrig, 2007)

\begin{tabular}{|c|c|c|c|}
\hline \multirow[b]{2}{*}{ TBI category } & \multirow[b]{2}{*}{ Description } & \multicolumn{2}{|c|}{ Example coding of terms from concept maps and statements from presentations } \\
\hline & & Precourse & Postcourse \\
\hline Traditional & $\begin{array}{l}\text { Teacher focused; teacher } \\
\text { delivers information to } \\
\text { students }\end{array}$ & $\begin{array}{l}\text { Term: Describe concepts } \\
\text { "There's things that you do...giving } \\
\text { anecdotes to explain the } \\
\text { concepts and how they might } \\
\text { come across what you're } \\
\text { teaching in their everyday life in } \\
\text { a way that they're already } \\
\text { familiar with ... so this would } \\
\text { be part of the lecture on the } \\
\text { main points." }\end{array}$ & $\begin{array}{l}\text { Term: Univocal } \\
\text { "These are more traditional teaching styles that we'd see in } \\
\text { a lecture sort of class ... They can convey information } \\
\text { much more quickly and they have higher stakes, but } \\
\text { they don't really get the students to do a whole lot of } \\
\text { thinking. They're sort of more passive." }\end{array}$ \\
\hline Instructive & $\begin{array}{l}\text { Teacher focused; teacher } \\
\text { provides experiences } \\
\text { and opportunities for } \\
\text { students to learn }\end{array}$ & $\begin{array}{l}\text { Term: Hands-on activity } \\
\text { "We kind of talked about how } \\
\text { doing these things, writing, } \\
\text { repetition, doing things } \\
\text { hands-on, those are ways to } \\
\text { help you hammer down } \\
\text { information, get the facts." }\end{array}$ & $\begin{array}{l}\text { Term: Drawing to learn } \\
\text { "There's more active drawing to learn or group work or } \\
\text { giving them thought problems to kind of integrate this } \\
\text { basic fact with this new knowledge." }\end{array}$ \\
\hline Transitional & $\begin{array}{l}\text { Teacher creates a } \\
\text { supportive and } \\
\text { positive classroom } \\
\text { environment, focused } \\
\text { on the student- } \\
\text { teacher relationship }\end{array}$ & $\begin{array}{l}\text { Term: Relatable } \\
\text { "And to be relatable and approach- } \\
\text { able so, if you can like make } \\
\text { yourself seem more on their } \\
\text { level so they can talk to you, } \\
\text { come and ask you questions, or } \\
\text { just be excited about what } \\
\text { you're teaching." }\end{array}$ & $\begin{array}{l}\text { Term: Care for diversity } \\
\text { "Everybody's gonna have different goals that maybe you } \\
\text { don't know or different challenges. You want to hit all } \\
\text { these different levels of learning based on the different } \\
\text { backgrounds." }\end{array}$ \\
\hline Responsive & $\begin{array}{l}\text { Student focused; teacher } \\
\text { encourages students' } \\
\text { interactions with peers }\end{array}$ & $\mathrm{N} / \mathrm{A}$ & $\mathrm{N} / \mathrm{A}$ \\
\hline Reform based & $\begin{array}{l}\text { Student focused; teacher } \\
\text { facilitates learning, } \\
\text { which is stu- } \\
\text { dent-driven }\end{array}$ & N/A & $\mathrm{N} / \mathrm{A}$ \\
\hline
\end{tabular}

in the precourse maps included providing students with examples or demonstrations, group activities, and creating an environment that encourages questions. Example statements representing traditional, instructive, and transitional beliefs from the concept map presentations are included in Table 2 and the following sections.

Traditional Ideas on Precourse Maps. Traditional ideas of delivering information to students included lecturing and providing examples. During the precourse map presentation, GTAs mentioned the need to deliver interesting lectures as a way to motivate students and improve learning. The term "creativity" was coded as traditional in group 1's precourse map, based on the statement extracted here and how creativity is associated with lectures, which is a means of information transmission.

By being creative in lecture, that allows you to have interest. It allows students to potentially be more interested in the material, so that they comprehend the material better.-Group 1
GTAs emphasized a need to provide relatable examples or demonstrations of the material to help with student learning (Table 2). Connecting the material to real-world examples was a common approach to teaching for GTAs. Similar to the "creativity" term, groups discussed terms like "examples" and "demonstrations" as a way to make the material interesting and personal to students. The terms "examples" and "demonstrations" were considered to be traditional rather than instructive when discussed, as students were passive and were expected to listen to examples or watch the demonstrations.

Instructive Ideas on Precourse Maps. Instructive ideas of providing students with experiences to learn included hands-on activities, quizzes, and group work. GTAs discussed many of these terms in the context of providing students with opportunities to learn without an explanation of why or how these opportunities would enable student learning in the classroom (Tables 1 and 2). These were considered instructive rather than responsive or reform based due to the limited rationale provided by the GTAs. 
TABLE 2. Frequency of common terms used in GTA concept maps

\begin{tabular}{|c|c|c|c|c|}
\hline \multirow[b]{2}{*}{ TBI category } & \multirow[b]{2}{*}{ Terms } & \multicolumn{2}{|c|}{ Frequency in (\%) } & \multirow[b]{2}{*}{ Example statements from concept map presentations } \\
\hline & & Precourse & Postcourse & \\
\hline \multirow[t]{2}{*}{ Traditional } & Lecture & $3(38)$ & $2(25)$ & $\begin{array}{l}\text { "I think a Power Point with bullet points and figures, and lecture things, recap } \\
\text { the previous lecture, and just lecture. So recapping the previous lecture ... is } \\
\text { to reinforce comprehension of the previous lecture." (precourse) }\end{array}$ \\
\hline & $\begin{array}{l}\text { Examples/ } \\
\text { metaphors }\end{array}$ & $7(88)$ & $3(38)$ & $\begin{array}{l}\text { "So the first thing we're discussing, which is demonstrations in general, is the } \\
\text { way to engage students ... Demonstrations being sort of an example of } \\
\text { concrete examples. It has to be an example that a student can take home ... } \\
\text { picking stories about genetics instead of the physical genes, describing } \\
\text { them." (precourse) }\end{array}$ \\
\hline \multirow[t]{5}{*}{ Instructive } & $\begin{array}{l}\text { Quizzes/tests/ } \\
\text { exams }\end{array}$ & $4(50)$ & $3(38)$ & $\begin{array}{l}\text { "Quizzes are just to help reinforce and try to give them a ... a reinforcement } \\
\text { that's point driven, so they have to go do it." (precourse) }\end{array}$ \\
\hline & Group work & $4(50)$ & $7(88)$ & $\begin{array}{l}\text { "You can, for this, you can give them some activities ... like small group } \\
\text { discussions.... Also, those discussions can promote the interactions." } \\
\text { (precourse) }\end{array}$ \\
\hline & $\begin{array}{l}\text { Hands-on/active } \\
\text { learning }\end{array}$ & $4(50)$ & $7(88)$ & $\begin{array}{l}\text { "So active learning where students teach students so they're active and they're } \\
\text { participating in a class." (postcourse) }\end{array}$ \\
\hline & Metacognition & $0(0)$ & $7(88)$ & $\begin{array}{l}\text { "So a teacher who uses these tools in a proper balance would then achieve the } \\
\text { goals of active learning and then their students would be thinking about } \\
\text { their thinking and thinking about their learning." (postcourse) }\end{array}$ \\
\hline & $\begin{array}{l}\text { Formative } \\
\text { assessment }\end{array}$ & $0(0)$ & $7(88)$ & $\begin{array}{l}\text { "But ideally, we want to focus on formative assessments, so weekly minute } \\
\text { papers, student presentations where they get rubrics and they continually } \\
\text { work on their assignments, and then reports where they're wrapping up the } \\
\text { concepts that they focused on at the beginning of the course." (postcourse) }\end{array}$ \\
\hline \multirow[t]{2}{*}{ Transitional } & $\begin{array}{l}\text { GTA characteristics } \\
\text { (approachable/ } \\
\text { relatable) }\end{array}$ & $4(50)$ & $1(13)$ & $\begin{array}{l}\text { "The manner in how you do these things. So do it in a non-intimidating } \\
\text { manner.... you just have a smile and be friendly and speak slowly and have } \\
\text { enthusiasm." (precourse) }\end{array}$ \\
\hline & Implicit bias/equity & $0(0)$ & $3(38)$ & $\begin{array}{l}\text { "If you are an immigrant female, and you're in a science class, and you use } \\
\text { examples of all these old white dudes who came up with all these scientific } \\
\text { principles so they might not connect to it. Versus, if you use women in } \\
\text { science or minorities as examples for the same kinds of topics that might } \\
\text { engage them more." (postcourse) }\end{array}$ \\
\hline
\end{tabular}

GTAs recognized the importance of group work as opportunities for students to interact with peers (Table 2). The terms "group work" or "group activities" were coded as instructive instead of responsive or reformed based, because they did not provide details of how peer interactions improved student learning or the GTAs' role in facilitating these interactions.

Transitional Ideas on Precourse Maps. Transitional ideas of fostering the student-teacher relationship revolved around relatability and approachability. Terms were coded as transitional when GTAs discussed why or how to develop studentteacher relationships (Tables 1 and 2). GTAs emphasized the importance of being approachable in the classroom to ensure students would feel comfortable to ask questions.

\section{Postcourse Concept Maps Dominated by Teacher-Focused Ideas on Learning}

The concept maps generated at the end of the pedagogy course (postcourse maps) consisted mainly of teacher-focused approaches to student learning. The terms on the postcourse maps were categorized as follows: $12.17 \%$ traditional, $76.97 \%$ instructive, and $10.86 \%$ transitional (Figure 2). There were no terms that were categorized as responsive or reform based. The percentage of instructive ideas was significantly greater than traditional $(p<0.001)$ and transitional $(p<0.001)$ ideas. An example postcourse map from group 3 is shown in Figure 3. The frequency of common themes in the postcourse maps is quantified in Table 2. Common themes in the postcourse maps included active learning, metacognition, and formative and summative assessments. Example statements representing traditional, instructive, and transitional beliefs from the postconcept map presentations are included in Table 2 the following sections.

Traditional Ideas on Postcourse Maps. Traditional ideas were still present in the postcourse maps, but they were not focal points of the concept maps. During the postcourse map presentations, GTAs included both the utility and limitations of lecturing as a means to transmit information in their explanations of the term "lecture." They recognized the passivity of the students while listening to a lecture (Table 1), which was not mentioned during the precourse presentations.

It's like these lecturing and repetition, those are instructor centric things that students will not really ever do.-Group 1

Instructive Ideas on Postcourse Maps. Instructive ideas represented most of the ideas on the postcourse maps, with particular emphasis on students being active in the classroom. Eight 


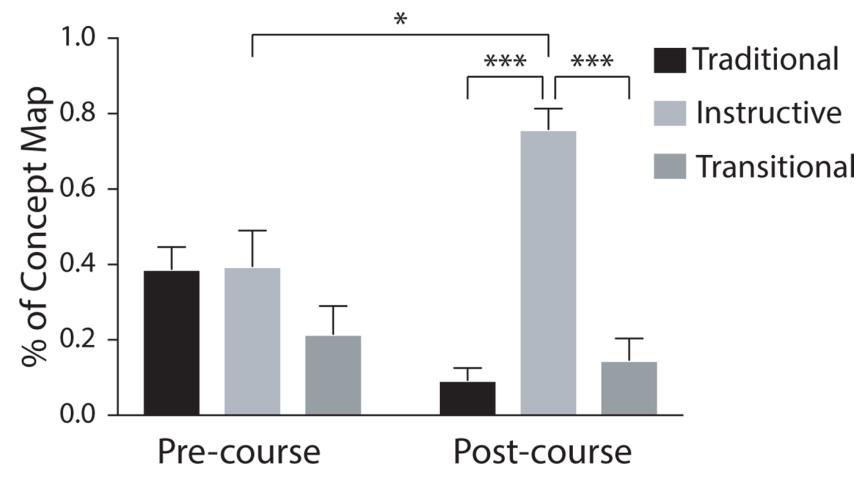

FIGURE 2. Precourse and postcourse maps of inexperienced GTAs' teachers' beliefs. There is no difference in TBI categories in the precourse maps ( $n=8$, mean \pm SEM). A two-way ANOVA with repeated measures revealed significant effects for TBI category $(F(2,14)=12.02, p<0.001)$. There was a significant interaction between the time point and TBI category $(F(2,14)=11.41, p<0.01)$. Analysis by Tukey's post hoc tests revealed that, compared with the precourse maps, there was a trend of less traditional ideas in the postcourse maps $(p=0.09)$ and there were significantly more instructive ideas of how students learn in the postcourse maps $(p<0.05)$. There was no change in the percentage of transitional ideas. The percentage of instructive ideas was significantly greater than traditional $(p<0.001)$ and transitional $(p<0.001)$ ideas. ${ }^{*} p<0.05 ;{ }^{* * *} p<0.001$.

of the eight postcourse maps included the term "active learning" or examples of active-learning activities. Based on the limited rationale provided for implementing these activities, the term "active learning" was coded as instructive rather than responsive or reform based (Tables 1 and 2).

GTAs emphasized that active learning was a way to promote or involve metacognition in the students (Table 2). Metacognition was included in seven of the eight postcourse maps. GTAs provided a definition of metacognition in their postcourse map presentations. However, due to absence of how or why active learning promoted metacognition and what the role of the instructor was beyond providing students with these activities

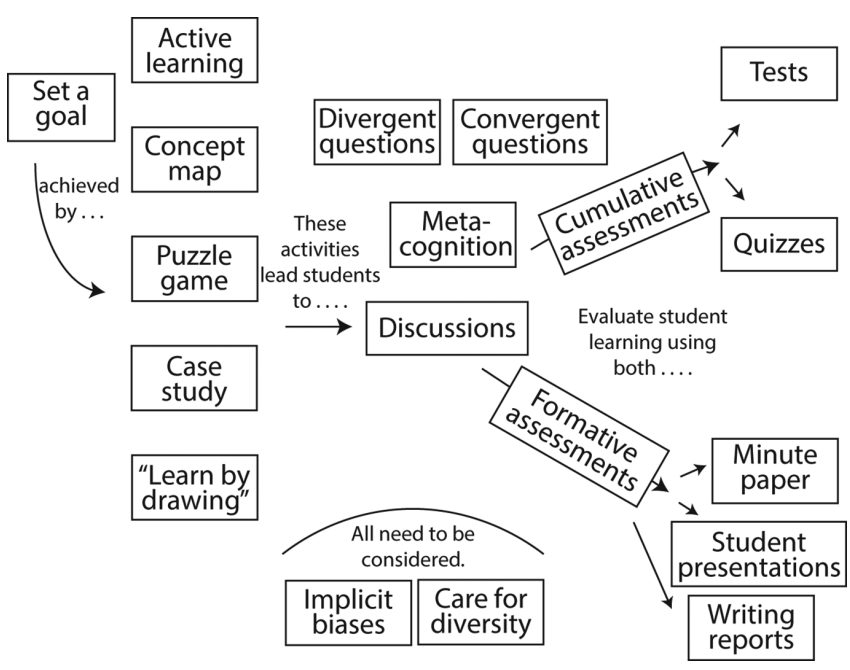

FIGURE 3. Representative postcourse map of inexperienced GTAs' teachers' beliefs concerning student learning. in the GTAs' presentation, the term "metacognition" was coded as instructive rather than reform based.

As in the precourse map presentations, GTAs recognized that peer interactions may contribute to student learning, but they did not provide reasons for why this may be useful or the GTAs' role in peer learning. In both pre- and postcourse maps, the terms "group work" or "group discussion" were coded as instructive instead of responsive, because the explanation was limited to wanting their students to participate and talk to their peers.

Like setting up an opportunity or environment for group discussion, or active learning, or bringing the student up in front of the class.... So just setting up those opportunities in the class.... And then it forces them to kind of understand it and then participate. Or, if we're creating group discussion, it's forcing them to talk it out with their peers.-Group 6

Formative and summative assessments were included in seven of the eight postcourse maps. GTAs provided examples of different types of formative assessments, including minute papers and lab reports, and expressed preference for using formative assessments over cumulative (summative) assessments.

Of course, we want to focus more on divergent questions, at which point we would want to evaluate their learning. We can do so through cumulative assessments, which are tests and quizzes. But ideally, we want to focus on formative assessments, so weekly minute papers, student presentations where they get rubrics and they continually work on their assignments, and then reports where they're wrapping up the concepts that they focused on at the beginning of the course.-Group 3

When asked a follow-up question of why they would want to focus more on formative rather than cumulative (summative) assessment, the GTA responded accordingly:

It was more so because we can continually see the students develop. When you give the students a test, I mean, you can also see it, but with the report, sometimes you see with students, they don't know how to write science. You don't really get to that issue in an exam. It's, okay, cool. You got the question right. I don't quite understand what you said, but it's right. Something like this, we could continually work on it. Yeah, we can always come back and test what they learned in the report and exam, but they're getting a lot more. They're learning how to write, and they're really thinking a lot more about what they're doing. There's a lot more metacognition, because they have to think about what's up here, and they have to synthesize it in a form that somebody else can understand.-Group 3

In this description, the GTA indicated formative assessments were more informative of the learning process and provided students with opportunities to improve their learning compared with summative assessments. Though the GTA provided a distinction between the two, the lack of details in how to implement or the role of GTAs in the assessments resulted in coding the terms "formative assessment" and "summative assessment" as instructive.

Transitional Ideas on Postcourse Maps. Transitional ideas included not only the ideas of GTAs being approachable and 
knowledgeable in the classroom, but also GTAs being equitable and inclusive. One group mentioned it was important to "provide a safe learning environment." Three of eight postcourse maps included terms such as "bias" and "equity." When asked how they might create a more inclusive classroom, the GTAs responded accordingly:

If you are an immigrant female, and you're in a science class, and you use examples of all these old white dudes who came up with all these scientific principles so they might not connect to it. Versus, if you use women in science or minorities as examples for the same kinds of topics that might engage them more.-Group 5

There was also a recognition that the students' backgrounds and motivations may be different from GTAs' own experiences (Table 2). This was in contrast to the precourse map presentations, in which GTAs focused on needing to motivate students without specification that student motivations may differ.

\section{Comparison of Pre- and Postcourse Maps}

For determination of whether the size of the concept maps differed between the pre- and postcourse maps, the number of terms was quantified. In the precourse maps, there was an average of 10.75 terms per map, with a range of seven to 19 terms. In the postcourse maps, there was an average of 14.88 terms per map, with a range of nine to 21 terms. There was a trend for an increased number of terms in the postcourse maps compared with precourse maps ( $p=0.09$; paired $t$ test).

There was a significant difference in the percentage of TBI categories in the precourse compared with the postcourse maps (Figure $2 ; F(2,14)=12.02, p<0.001)$. There was a significant interaction between the time point and TBI category $(F(2,14)=$ $11.41, p<0.01)$. Compared with the precourse maps, there was a trend of less traditional ideas in the postcourse maps ( $p=$ 0.09). This is reflected in the frequency of lecture and examples/metaphors in pre- compared with postcourse maps (Table 2 ). There were significantly more instructive ideas of how students learn in the post- than precourse maps $(p<0.05)$. This is exemplified in the frequency of terms such as "metacognition" and "formative assessments" in postcourse maps (Table 2). There was no change in the percentage of transitional ideas between GTAs' pre- and postcourse maps.

\section{DISCUSSION}

Understanding the teaching beliefs of GTAs is critical to understanding their teaching practices. This study characterized the teaching beliefs of inexperienced GTAs using concept maps before and after PD. The inexperienced GTAs' beliefs on student learning were teacher focused at the beginning of the pedagogy course; they did not change as a group and remained mainly teacher focused at the end of the quarter-long science pedagogy course. In the beginning of the course, GTAs discussed traditional, instructive, and transitional approaches to maximize their students' learning. Although GTAs' beliefs remained teacher focused, there was a significant shift in the GTAs' beliefs being more instructive than traditional at the end of the course; the GTAs discussed providing experiences and opportunities for students to learn with an emphasis on active students.
In the precourse maps, GTAs focused on providing relatable examples to capture the students' interests and motivate them to learn the concepts, which is similar to inexperienced teachers, who do not focus on student learning and are more preoccupied with students' interests and motivation (Abell et al., 1998; Davis et al., 2006). Personal experiences are a key component of teachers' beliefs (Nespor, 1987), and preservice teachers fondly remember formative experiences that stimulated their own interest in science (Abell et al., 1998). This may also help explain why GTAs emphasized on precourse maps the use of group work and hands-on activities to get students engaged in the material in a memorable way. However, other than being active, there was no mention during the precourse map presentations of how or why students would learn the concepts in this manner. Assessment of student learning revolved around quizzes and tests, suggesting the GTAs' experiences as students were limited to summative assessments. This is consistent with GTAs who focus on information transmission and believe assessing student learning occurs primarily through quizzes and tests (Hammrich, 2001).

In both the pre- and postcourse maps, GTAs recognized the importance of developing a student-teacher relationship and classroom environment that enabled students to ask questions. At the beginning of the course, GTAs were preoccupied with being an affable and did not focus on how they might influence their classroom climate. This is consistent with inexperienced GTAs going through developmental stages, with the first stage focused on self/survival skills, including whether students will like them, and not concerned about student learning (Nyquist and Wulff, 1996). Similarly, preservice teachers' concept maps emphasized classroom management and personal characteristics (Beyerbach and Smith, 1990). By the end of the course, GTAs recognized the student-teacher relationship went beyond personal characteristics. It would depend on a number of factors, including recognizing GTAs' backgrounds, experiences, and motivations as undergraduate students may be different from those of the undergraduate students in their classrooms. GTAs included the terms "bias" and "equity" in the postcourse maps, which were not included in the precourse maps, and may have been a result of discussing a paper on inclusive classrooms.

One noticeable difference between the pre- and postcourse maps is the use of jargon. The jargon in the postcourse maps was evident and derived from the pedagogy papers from the course. GTAs mentioned students participating in activities to help promote metacognition, with one group stating that the goal of active-learning activities is metacognition. GTAs provided a definition for metacognition, but they did not explain how or why metacognition would occur with active students. Similarly, when GTAs discussed the terms "active learning" and "formative assessment" in the postcourse maps, they provided superficial descriptions of the terms without any details of how or why those items would improve student learning. This finding is consistent with preservice teachers who use buzzwords without an explanation of their use or application in their views of science teaching and learning (Abell et al., 1998). It was unclear how GTAs would facilitate the learning process during these activities, which may have been difficult for GTAs to articulate, as they often struggle with facilitating discussions and motivating student participation (Gormally et al., 2016). This 
demonstrates that the pedagogy course introduced pedagogical terminology to GTAs, but it did not enable GTAs to discuss the strategies at the level of practice and implementation.

Throughout the course, the role of GTAs in student learning was a common discussion thread, emphasizing how students learn and how GTAs may support this process. From the start of the course, GTAs were challenged in their thinking about the effectiveness of traditional teaching strategies through discussions of the weekly readings and the active-learning activity. At the end of the pedagogy course, GTAs' beliefs on student learning were mainly instructive, with GTAs focused on providing opportunities and experiences for students to learn. This was illustrated in the postcourse maps by GTAs' emphasis on providing students with activities that would require students to participate. This finding indicates that the pedagogy course was effective in GTAs' recognizing the limitations of traditional teaching strategies with passive students and favoring instructive teaching strategies with active students.

A number of aspects of the pedagogy course may have contributed to changing the GTAs' teaching beliefs. Discipline-specific PD is more effective at shifting teaching beliefs compared with general PD (Luft, 2009). The course focused on how to teach biology effectively in lab and discussion sections. Course enrollment was limited to biology GTAs, who were all teaching courses within one department. Collective participation and constructive interactions among peers are also critical for effective PD for teachers (Garet et al., 2001; Desimone, 2009). The small class size allowed for a supportive classroom environment in which all GTAs actively shared their classroom experiences and received feedback from instructors and their peers. These discussions offered GTAs multiple suggestions on how to manage a classroom and implement teaching strategies, with an emphasis that ideas may need to be tailored to individual GTAs. Other recommendations for GTA training programs include emphasizing student learning, practicing pedagogical skills, and providing opportunities to self-reflect on teaching (Luo et al., 2000; Park, 2004; Gardner and Jones, 2011), all of which were embedded in the course through the active-learning activity and biweekly reflections.

Incorporating the key features of GTA training programs into the course was essential to shift the beliefs from traditional to instructive, but it did not change the GTAs' beliefs from being teacher focused to student focused. Given the complex nature of teachers' beliefs, it may have been expected that GTAs' beliefs would not change from teacher focused to student focused after one quarter of PD. It is possible the inexperienced GTAs needed more classroom experiences and time to reflect and integrate discipline-based education research into their beliefs and practices.

Though longer than the presemester orientation, the quarter-long course would still not be considered long-term support, which is another recommended feature of GTA PD. Providing teachers with long-term PD can change beliefs to be more student centered (Fennema et al., 1996). Continuing to support the GTAs in their future teaching assignments may be necessary for GTAs to adopt student-centered beliefs. The lack of instructional support represents a major barrier for GTAs in implementing new teaching strategies (Goodwin et al., 2018). Addressing both long-term support and changing teaching beliefs are the most effective approaches to changing teaching practices (Henderson et al., 2011).

\section{LIMITATIONS}

One limitation of the study is the generation of concept maps by groups of GTAs as opposed to individual GTAs. Asking students to work in groups was intended to allow for brainstorming of ideas among the GTAs and create more comprehensive maps. Though each GTA contributed to the maps generated by his or her group, the summary of teaching beliefs illustrated and discussed in the pre- and postcourse maps may not reflect the beliefs of individual GTAs. The groups were mixed, with mostly GTAs with no teaching experience and those with at most a year of teaching experience. Though preservice and first-year teachers are considered to be in a similar stage of teacher development (Kagan, 1992), it is unknown how GTAs progress through the stages of teacher development. The impact of the pedagogy course on GTAs' beliefs may have been influenced by prior teaching experience and developmental stage. Finally, it is possible that the time given in creating and presenting the concept map constrained the conversation, and in-depth interviews would have better captured a change in beliefs concerning student learning.

The concept maps and presentations may have also been limited due to GTAs' inexperience in thinking about and discussing teaching. Beyond the pedagogical terminology, some GTAs expressed uncertainty in how to answer the focus question of the concept map in the first class. Because GTAs only attended a campus-wide workshop before the course, this class may have provided their first opportunity to consider the GTA role and how their actions impact student learning. The difficulty in answering the focus question may be due to the emphasis on student learning, rather than on how GTAs prepared themselves for teaching. Inexperienced GTAs are preoccupied with self and how to survive the classroom rather than student learning (Nyquist and Wulff, 1996). Participating in PD increases the likelihood that GTAs are concerned about student learning (Cho et al., 2011). The pedagogy course emphasized student learning, and GTAs may have been better prepared to answer the focus question in the postcourse concept maps.

\section{CONCLUSIONS}

The concept maps generated by groups illustrate the malleable nature of beliefs, which may be shaped by PD. Supporting inexperienced GTAs early in their teaching experiences represents an opportunity to potentially change beliefs from teacher focused to student focused, because inexperienced teachers are more likely to change their beliefs than experienced teachers (Luft, 2001). Inexperienced GTAs' beliefs can change with $\mathrm{PD}$, which is discipline specific, emphasizes student learning, and allows for practice of pedagogical skills. This study suggests that a quarter-long, science-specific pedagogy course is insufficient for shifting inexperienced GTAs' beliefs from teacher focused to student focused, but it did shift GTAs' beliefs from traditional to instructive, and there is a need to provide additional PD as GTAs develop and strengthen their beliefs surrounding teaching and learning. Long-term PD will be essential to further explore the role of GTAs and how they can better facilitate student learning. Support will also need to be tailored to the individual needs of GTAs, who will vary in their backgrounds, including incoming beliefs and classroom experiences. 


\section{ACKNOWLEDGMENTS}

I thank the GTAs who participated in this study, Marsha Ing for her input and assistance with the study, Michael Fugate for his assistance in developing and teaching Biology 301, and Katie Burnette for her assistance in teaching Biology 301. This research on GTAs teaching PD was conducted as part of the BioTAP Scholars program, a component of the Biology Teaching Assistant Project (BioTAP; National Science Foundation RCN-UBE grant \#DBI-1247938).

\section{REFERENCES}

Abell, S. K., Bryan, L. A., \& Anderson, M. A. (1998). Investigating preservice elementary science teacher reflective thinking using integrated media case-based instruction in elementary science teacher preparation. Science Education, 82(4), 491-509.

Addy, T. M., \& Blanchard, M. R. (2010). The problem with reform from the bottom up: Instructional practices and teacher beliefs of graduate teaching assistants following a reform-minded university teacher certificate programme. International Journal of Science Education, 32(8), 1045-1071.

Allen, D., \& Tanner, K. (2003). Approaches to cell biology teaching: Mapping the journey-concept maps as signposts of developing knowledge structures. Cell Biology Education, 2(3), 133-136.

Austin, A. E. (2002). Preparing the next generation of faculty. Journal of Higher Education, 73(1), 94-122.

Beyerbach, B. A., \& Smith, J. M. (1990). Using a computerized concept mapping program to assess preservice teachers' thinking about effective teaching. Journal of Research in Science Teaching, 27(10), $961-$ 971.

Borda, E. J., Burgess, D. J., Plog, C. J., DeKalb, N. C., \& Luce, M. M. (2009) Concept maps as tools for assessing students' epistemologies of science. Electronic Journal of Science Education, 13(2), 160-185

Brownell, S. E., \& Tanner, K. D. (2012). Barriers to faculty pedagogical change: Lack of training, time, incentives, and ... tensions with professional identity? CBE-Life Sciences Education, 11(4), 339-346

Carey, S. (1986). Cognitive science and science education. American Psychologist, 41(10), 1123-1130.

Chichekian, T., \& Shore, B. M. (2013). Concept maps provide a window onto preservice elementary teachers' knowledge in the teaching and learning of mathematics. Canadian Journal of Education, 36(3), 47-71

Cho, Y., Kim, M., Svinicki, M. D., \& Decker, M. L. (2011). Exploring teaching concerns and characteristics of graduate teaching assistants. Teaching in Higher Education, 16(3), 267-279.

Connolly, M. R., Lee, Y.-G., \& Savoy, J. N. (2018). The effects of doctoral teaching development on early-career STEM scholars' college teaching self-efficacy. CBE-Life Sciences Education, 17, ar14.

Connolly, M. R., Savoy, J. N., Lee, Y.-G., \& Hill, L. B. (2016). Building a better future STEM faculty: How doctoral teaching programs can improve undergraduate education. Madison: Wisconsin Center for Education Research, University of Wisconsin-Madison

Dancy, M., Henderson, C., \& Turpen, C. (2016). How faculty learn about and implement research-based instructional strategies: The case of peer instruction. Physical Review Physics Education Research, 12(1), 010110.

Davis, E. A., Petish, D., \& Smithey, J. (2006). Challenges new science teachers face. Review of Educational Research, 76(4), 607-651.

DeChenne, S. E., Enochs, L. G., \& Needham, M. (2012). Science, technology، engineering, and mathematics graduate teaching assistants teaching self-efficacy. Journal of the Scholarship of Teaching and Learning, 12(4) 102-123.

Desimone, L. M. (2009). Improving impact studies of teachers' professional development: Toward better conceptualizations and measures. Educational Researcher, 38(3), 181-199.

Douglas, J., Powell, D. N., \& Rouamba, N. H. (2016). Assessing graduate teaching assistants' beliefs and practices. Journal on Excellence in College Teaching, 27(3), 35-61

Feiman-Nemser, S. (2001). From preparation to practice: Designing a continuum to strengthen and sustain teaching. Teachers College Record, 103(6), 1013-1055.
Feldon, D. F., Peugh, J., Timmerman, B. E., Maher, M. A., Hurst, M., Strickland D., ... Stiegelmeyer, C. (2011). Graduate students' teaching experiences improve their methodological research skills. Science, 333(6045), 10371039.

Fennema, E., Carpenter, T. P., Franke, M. L., Levi, L., Jacobs, V. R., \& Empson S. B. (1996). A longitudinal study of learning to use children's thinking in mathematics instruction. Journal for Research in Mathematics Education, 27(4), 403-434.

Gardner, G. E., \& Jones, M. G. (2011). Pedagogical preparation of the science graduate teaching assistant: Challenges and implications. Science Educator, 20(2), 31-41.

Garet, M. S., Porter, A. C., Desimone, L., Birman, B. F., \& Yoon, K. S. (2001). What makes professional development effective? Results from a national sample of teachers. American Educational Research Journal, 38(4), 915945

Golde, C. M., \& Dore, T. M. (2001). At cross purposes: What the experiences of today's doctoral students reveal about doctoral education. Philadelphia: Pew Charitable Trusts Report.

Goodwin, E. C., Cao, J. N., Fletcher, M., Flaiban, J. L., \& Shortlidge, E. E. (2018). Catching the wave: Are biology graduate students on board with evidence-based teaching? CBE-Life Sciences Education, 17, $\operatorname{ar} 43$

Gormally, C., Sullivan, C. S., \& Szeinbaum, N. (2016). Uncovering barriers to teaching assistants (TAs) implementing inquiry teaching: Inconsistent facilitation techniques, student resistance, and reluctance to share control over learning with students. Journal of Microbiology \& Biology Education, 17(2), 215-224.

Hammrich, P. L. (2001). Preparing graduate teaching assistants to assist biology faculty. Journal of Science Teacher Education, 12(1), 67-82.

Henderson, C., Beach, A., \& Finkelstein, N. (2011). Facilitating change in undergraduate STEM instructional practices: An analytical review of the literature. Journal of Research in Science Teaching, 48(8), 952984

Jones, J. L. (1993). TA training: From the TA's point of view. Innovative Higher Education, 18(2), 147-161.

Jones, M. G., \& Vesilind, E. M. (1996). Putting practice into theory: Changes in the organization of preservice teachers' pedagogical knowledge. American Educational Research Journal, 33(1), 91-117

Kagan, D. M. (1990). Ways of evaluating teacher cognition: Inferences concerning the Goldilocks principle. Review of Educational Research, 60(3) 419-469.

Kagan, D. M. (1992). Professional growth among preservice and beginning teachers. Review of Educational Research, 62(2), 129-169.

Keys, C. W., \& Bryan, L. A. (2001). Co-constructing inquiry-based science with teachers: Essential research for lasting reform. Journal of Research in Science Teaching, 38(6), 631-645.

Lederman, N. G., Gess-Newsome, J., \& Latz, M. S. (1994). The nature and development of preservice science teachers' conceptions of subject matter and pedagogy. Journal of Research in Science Teaching, 31(2) 129-146.

Lee, E., Brown, M. N., Luft, J. A., \& Roehrig, G. H. (2007). Assessing beginning secondary science teachers' PCK: Pilot year results. School Science and Mathematics, 107(2), 52-60.

Luft, J. A. (2001). Changing inquiry practices and beliefs: The impact of an inquiry-based professional development programme on beginning and experienced secondary science teachers. International Journal of Science Education, 23(5), 517-534.

Luft, J. A. (2009). Beginning secondary science teachers in different induction programmes: The first year of teaching. International Journal of Science Education, 31(17), 2355-2384.

Luft, J. A., Kurdziel, J. P., Roehrig, G. H., \& Turner, J. (2004). Growing a garden without water: Graduate teaching assistants in introductory science laboratories at a doctoral/research university. Journal of Research in Science Teaching, 41(3), 211-233.

Luft, J. A., \& Roehrig, G. H. (2007). Capturing science teachers' epistemological beliefs: The development of the teacher beliefs interview. Electronic Journal of Science Education, 11(2), 38-63.

Luft, J. A., Roehrig, G. H., \& Patterson, N. C. (2003). Contrasting landscapes: A comparison of the impact of different induction programs on 
beginning secondary science teachers' practices, beliefs, and experiences. Journal of Research in Science Teaching, 40(1), 77-97.

Luo, J., Bellows, L., \& Grady, M. (2000). Classroom management issues for teaching assistants. Research in Higher Education, 41(3), 353-383.

Magnusson, S., Krajcik, J., \& Borko, H. (1999). Nature, sources, and development of pedagogical content knowledge for science teaching. In Gess-Newsome, J., \& Lederman, N. (Eds.), Examining pedagogical content knowledge: The construct and its implications for science education (pp. 95-132). Dordrecht, Netherlands: Kluwer Academic.

Marbach-Ad, G., Schaefer, K. L., Kumi, B. C., Friedman, L. A., Thompson, K. V., $\&$ Doyle, M. P. (2012). Development and evaluation of a prep course for chemistry graduate teaching assistants at a research university. Journal of Chemical Education, 89, 865-872.

Markham, K. M., \& Mintzes, J. J. (1994). The concept map as a research and evaluation tool: Further evidence of validity. Journal of Research in Science Teaching, 31(1), 91-101.

Morine-Dershimer, G., Saunders, S., Artiles, A. J., Mostert, M. P., Tankersley, M., Trent, S. C., \& Nuttycombe, D. G. (1992). Choosing among alternatives for tracing conceptual change. Teaching \& Teacher Education, 8(5-6), 471-483.

Nesbit, J. C., \& Adesope, O. O. (2006). Learning with concept and knowledge maps: A meta-analysis. Review of Educational Research, 76(3), 413-448.

Nespor, J. (1987). The role of beliefs in the practice of teaching. Journal of Curriculum Studies, 19(4), 317-328.

Norton, L., Richardson, J. T. E., Hartley, J., Newstead, S., \& Mayes, J. (2005). Teachers' beliefs and intentions concerning teaching in higher education. Higher Education, 50(4), 537-571.

Novak, J. D., \& Cañas, A. J. (2008). The theory underlying concept maps and how to construct and use them (Technical report IHMC CmapTools 2006-01 Rev 01-2008). Pensacola: Florida Institute for Human and Machine Cognition. Retrieved April 4, 2016, from http://cmap.ihmc.us/ Publications/ResearchPapers/TheoryUnderlyingConceptMaps.pdf

Novak, J. D., \& Gowin, D. B. (1984). Learning how to learn. New York: Cambridge University Press.

Nyquist, J. D., \& Wulff, D. H. (1996). Working effectively with graduate assistants. Thousand Oaks, CA: Sage.

Okebukola, P. A., \& Jegede, O. J. (1988). Cognitive preference and learning mode as determinants of meaningful learning through concept mapping. Science Education, 72(4), 489-500.

Pajares, M. F. (1992). Teachers' beliefs and educational research: Cleaning up a messy construct. Review of Educational Research, 62(3), 307-332.

Park, C. (2004). The graduate teaching assistant (GTA): Lessons from North American experience. Teaching in Higher Education, 9(3), 349-361.

Park, C., \& Ramos, M. (2002). The donkey in the department? Insights into the graduate teaching assistant (GTA) experience in the UK. Journal of Graduate Education, 3(2), 47-53.
Postareff, L., Lindblom-Ylänne, S., \& Nevgi, A. (2008). A follow-up study of the effect of pedagogical training on teaching in higher education. Higher Education, 56(1), 29-43.

Reeves, T. D., Hake, L. E., Chen, X., Frederick, J., Rudenga, K., Ludlow, L. H., \& O'Connor, C. M. (2018). Does context matter? Convergent and divergent findings in the cross-institutional evaluation of graduate teaching assistant professional development programs. CBE-Life Sciences Education, 17 , ar8.

Reeves, T. D., Marbach-Ad, G., Miller, K. R., Ridgway, J., Gardner, G. E., Schussler, E. E., \& Wischusen, E. W. (2016). A conceptual framework for graduate teaching assistant professional development evaluation and research. CBE-Life Sciences Education, 15, es2.

Roehrig, G. H., Luft, J. A., Kurdziel, J. P., \& Turner, J. A. (2003). Graduate teaching assistants and inquiry-based instruction: Implications for graduate teaching assistant training. Journal of Chemical Education, 80(10), $1206-1210$.

Rushin, J. W., DeSaix, J., Lumsden, A., Streubel, D. P. Summers, G. \& Bernson C. (1997). Graduate teaching assistant training: A basis for improvement of college biology teaching \& faculty development? American Biology Teacher, 59(2), 86-90.

Schussler, E. E., Read, Q., Marbach-Ad, G., Miller, K., \& Ferzli, M. (2015) Preparing biology graduate teaching assistants for their roles as instructors: An assessment of institutional approaches. CBE-Life Sciences Education, 14(3), ar31.

Shortlidge, E. E., \& Eddy, S. L. (2018). The trade-off between graduate student research and teaching: A myth? PLOS ONE, 13(6), e0199576.

Shulman, L. S. (1986). Those who understand: Knowledge growth in teaching. Educational Researcher, 15(2), 4-14.

Sundberg, M. D., Armstrong, J. E., \& Wischusen, W. (2005). A reappraisal of the status of introductory biology laboratory education in U.S. colleges and universities. American Biology Teacher, 67(9), 525-529.

Trigwell, K., Prosser, M., \& Taylor, P. (1994). Qualitative differences in approaches to teaching first year university science. Higher Education, 27(1), 75-84.

van Boxtel, C., van der Linden, J., Roelofs, E., \& Erkens, G. (2002). Collaborative concept mapping: Provoking and supporting meaningful discourse. Theory into Practice, 41(1), 40-46.

van der Linden, W., Bakx, A., Ros, A., Beijaard, D., \& van den Bergh, L. (2015). The development of student teachers' research knowledge, beliefs and attitude. Journal of Education for Teaching, 41(1), 4-18.

Wyse, S. A., Long, T. M., \& Ebert-May, D. (2014). Teaching assistant professional development in biology: Designed for and driven by multidimensional data. CBE-Life Sciences Education, 13(2), 212-223.

Zanting, A., Verloop, N., \& Vermunt, J. D. (2003). Using interviews and concept maps to access mentor teachers' practical knowledge. Higher Education, 46(2), 195-214. 